\title{
COLONY COMPOSITION IN FOUR SPECIES OF POLISTINAE FROM SURINAME, WITH A DESCRIPTION OF THE LARVA OF BRACHYGASTRA SCUTELLARIS (HYMENOPTERA: VESPIDAE)
}

\author{
By James M. Carpenter* and Kenneth G. Ross**
}

\section{INTRODUCTION}

Knowledge of the social structure in colonies of tropical Polistinae remains fragmentary. Since the pioneering studies of Richards and Richards (1951), capture and dissection of the adult population of a nest has been the primary method for reconstruction of the caste composition of a species. As the reviews of Jeanne (1980) and Akre (1982) document, long-term observational studies are increasingly contributing to behavioral analysis in this group. Yet the prevailing view of social structure in swarm-founding Polistinae is still largely based upon limited studies of a few species. Indeed, most of the species studied by Richards and Richards (1951) have not been re-examined.

While participating in the Second Cornell Suriname Expedition, the senior author collected five colonies of three of the species studied by Richards and Richards (1951), and one species studied by Richards (1978). Dissection of the specimens revealed certain discrepancies with the published accounts of colony composition for these species, as well as new information. These results are presented below, together with descriptive notes on the nests. The larvae of Polybia bistriata, P. catillifex and Metapolybia cingulata have beęn described by Reid (1942). He also described the larva of a Brachygastra species, termed by him Nectarinia scutellaris. However, Richards (1978: 166) stated that the nests he had obtained in Guyana, upon which Reid based his work, were actually those of the species myersi. The larva of $B$. scutellaris has thus never been described. A description is included in this paper.

\footnotetext{
*Museum of Comparative Zoology, Harvard University, Cambridge, Massachusetts 02138.

**Department of Entomology, University of Georgia, Athens, Georgia 30602 Manuscript received by the editor May 11, 1984.
} 


\section{Methods}

The colonies were collected during February 1982 in the Raleigh Vallen-Voltzberg Natuureservaat (Foengoe Eiland $4^{\circ} 42^{\prime} \mathrm{N}, 56^{\circ} 12^{\prime \prime} \mathrm{W}$, approximately $90 \mathrm{~m}$ elev.; Voltzberg Camp $4^{\circ} 42^{\prime} \mathrm{N}, 56^{\circ} 13^{\prime} \mathrm{W}$, also $90 \mathrm{~m})$, Saramacca Dist., Suriname. The nests were placed in plastic bags and the adults killed with "wasp freeze". Adults and larvae were both preserved in Dietrich's fluid until dissection. All female wasps were dissected and various measurement data taken with an optical micrometer. Length of the discal cell (M1) was used as a measure of wing length; the left wing was excised and flattened in a drop of glycerin for measurement. No notable wing wear was found for any of the wasps. A modified Cumber ovariole index (Cumber, 1949) was used to quantify ovarian development, with an additional count of oocytes greater than $0.6 \mathrm{~mm}$ in length (considered "developed") as a check. Inseminated individuals could readily be distinguished by the pronounced reddish-golden color of the spermatheca; nevertheless all spermathecae were examined under phase-contrast microscope. Sperm were visible as an agglutinated mass in the lumen (Fig. 1). Classification into castes separated queens (inseminated individuals), intermediates (uninseminated but with an ovariole index of 1 or more) and workers (uninseminated, index $=0$ ). Richards' gland (on metasomal sternum V) was present in all species (Fig. 2). No caste differences were observed in this structure.

Exploratory data analysis (Velleman and Hoaglin, 1981) was performed, with further analysis where results indicated. Analyses included investigations of the relationship between the various morphometric measures (were the correlations positive, and so reflections of general size?), the relationship between these and ovarian development (is size associated with reproductive capacity?), and differences between castes in these measurements. The data were normally distributed, therefore the results of t-tests are reported for caste differences.

Larvae were examined with the aid of cuticular stains (acid fuchsin, Grenacher's alcoholic borax-carmine, eosin-Y). Mouthparts and the frontoclypeal region of $B$. scutellaris were excised, and the latter examined under phase-contrast miscroscope.

Voucher specimens of all species have been deposited in the Cornell University Insect Collection, Lot number 1129. 


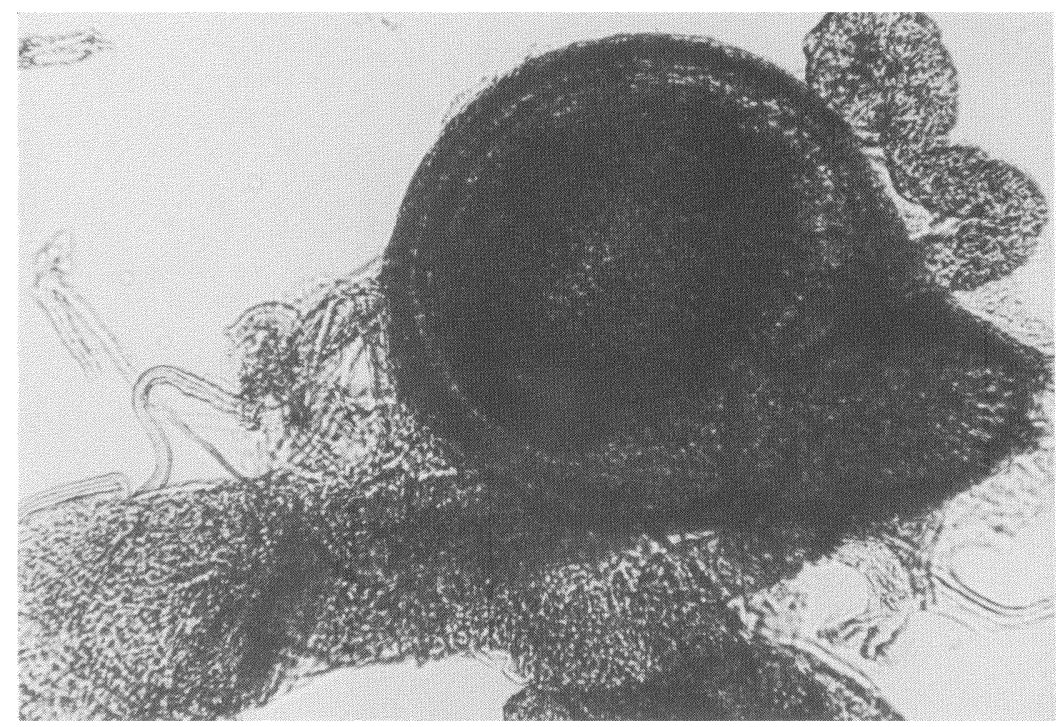

Fig. 1. Brach!gastra scutellaris, spermatheca with sperm in lumen.

\section{RESULTS}

\section{Polybia bistriata:}

Two colonies of this species were collected on Foengoe Eiland on February 4 . The nests were located within $4 \mathrm{~m}$ of one another on the undersides of leaves in shaded secondary growth along a path. Both were about $1.5 \mathrm{~m}$ above the ground and thus inconspicuous. Several adults escaped from each nest.

The nests were similar in appearance, and of the same shape and size as depicted in Figs. 19-21 of Richards and Richards (1951). The envelope was whitish-gray with brown streaks, and moderately flexible. Under high magnification, fragments of plant tissue were distinguishable among masticated, somewhat granular material. The envelopes were built by the "edge technique" (Jeanne, 1973), and were not thickened. They were evidently the products of single construction efforts, and no growth lines were present. The entrances were slightly off-center and ventral, unlike Fig. 19 of Richards and Richards but like those described in the text (p. 56). 


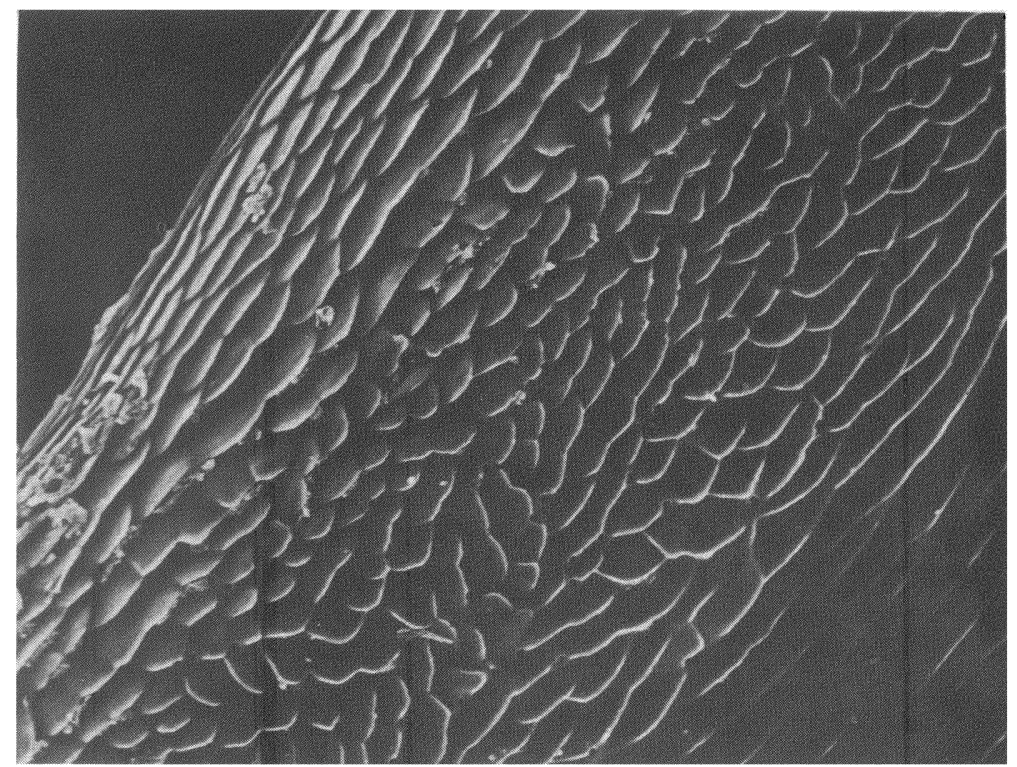

Fig. 2. Polyhia catillifex, Richard's gland (700×), ventral view.

The first colony (82-02-04-1) contained a single comb of 147 uncapped cells, 24 of which contained early-instar larvae and 48 with eggs. These were concentrated in the center of the comb. No sign of cell re-use was present; the nest appeared to be quite young. Twenty-six adults were captured, six of which proved to be queens. Among the 20 workers, one had developing oocytes in the ovarioles, but these were still smaller than the accompanying trophocyte masses. Measurements consisted of maximum apical width of metasomal tergum I and length of this segment taken from the ligament base to the apex, as well as length of the discal cell. The tergal measurements were not significantly correlated with each other (all $\mathrm{N}=26 ; \mathrm{r}=.303$, Pearson product-moment correlation), but were correlated with length of the discal cell $(r=.482, p<.05$ for tergal width; $r=.488, p<.01$ for length). Hamulus number was not significantly correlated with any measurement $(r=.063$ for tergal width, .076 for length, and .157 for discal cell length). Only discal cell length was significantly correlated, negatively, with ovariole index 
$(\mathrm{r}=-.443, \mathrm{p}<.05)$, however, the trends were also negative for the other measurements $(r=-.307$ for tergal width, -.338 for length, and -.050 for hamulus number). Queens did not differ significantly from workers in tergal width, discal cell length or hamulus number $(\mathrm{t}=-1.883,-1.917$, and 0.070 , respectively). Queens had significantly shorter terga than workers when compared by a t-test $($ mean $=1.47 \mathrm{~mm}$ versus $1.52, \mathrm{t}=-2.470, \mathrm{p}<.03)$.

The second colony (82-02-04-2) had a comb of 151 cells. Of these, 25 were capped, and some contained partly melanized pupae. There were also late-instar larvae in some uncapped cells; the number could not be ascertained due to damage to the nest, but was not greater than 12. Other cells were empty. No sign of cell re-use was present, and the occupied cells were irregularly arranged but mostly central. This colony was probably also producing its first brood. Forty-six adult wasps were taken, of which seven were queens and 39 workers. Of the latter, 11 had slightly developed oocytes, but the index was 0 . The tergal width and length were significantly correlated, both with each other (all $N=46 ; r=.375$, $\mathrm{p}<.01)$ and with length of the discal cell $(\mathrm{r}=.567, \mathrm{p}<.01$ for tergal width; $r=.726, p<.01$ for length). As in the previous colony, hamulus number was not significantly correlated with the other measurements. No measurements were correlated with ovariole index $(\mathrm{r}=.026$ for tergal width, -.032 for tergal length, -.219 for discal cell, and -.234 for hamulus number). Queens did not differ significantly from workers by any measure $(t=0.277$ for tergal width, -0.168 for tergal length, -1.495 for discal cell length, and -1.356 for hamulus number).

When the morphometric data for each colony were pooled, significant correlations were found between all measurements, but not hamulus number. When further examined, the colonies differed significantly in tergal width, with colony 2 having workers with narrower terga (mean $=0.73 \mathrm{~mm}$ versus $0.76 ; \mathrm{t}=-3.353, \mathrm{p}<.002)$. No correlation with ovariole index occurred in the pooled data, but all trends were negative. Summing up, it appears that queens are slightly smaller than workers but the differences are not generally significant in these young colonies.

Richards and Richards (1951) reported significant differences between queens and workers in hamulus number in this species, and this result has been widely cited (e.g. Richards, 1978; Jeanne, 1980). 
They studied 14 colonies in varying states of development, and counted hamulus number in 138 wasps drawn from an unspecified number of these colonies. Queens had a larger average number of hamuli. While their results were based on a larger sample size, these authors could not check for sperm in the spermatheca, and so classified caste solely on the basis of ovariole condition. Workers were those with filamentous ovarioles and no "developed rudiments" (this term was not defined), and queens "nearly always" had some "ripe" eggs and a number of enlarged rudiments. They recognized an intermediate caste in three colonies, with "two or three rudiments more or less enlarged". These probably corresponded to our workers with some developed eggs (length $>0.6 \mathrm{~mm}$, index $=0$ ). They further pointed out that their queens of one colony would have been classified as intermediates if "a typical queen" had been found. Without details on the source of their sample it is difficult to infer a complete explanation of their different results. However, their measure of wing length showed the same trend as ours: queens appear to be slightly smaller. The difference in mean hamulus number, with the queens having the larger value, may be at odds with this trend (cf. Richards, 1949 on a generally positive relationship between wing length and hamulus number). Therefore, some individuals were probably misclassified. At the very least, their result does not obtain for all colonies of this species (and probably not for all of theirs), and we believe it is generally not valid.

\section{Polybia catillifex:}

One colony of this species (82-02-03-1) was collected at Voltzberg Camp on February 2. It was in primary "liana forest" on a low vine, and inconspicuous. The envelope obscured the petiole, which was attached to a twig at the base of two leaflets. These had been curled around and attached to the apices of the peripheral cells, and the envelope also was built over their bases. The total area of the comb was approximately $38 \times 32 \mathrm{~mm}$. The paper was brown, and composed of tough plant fragments and some granular material. It was somewhat brittle, and had been built by the edge technique. Material had been added dorsally but in an irregular fashion; the envelope was considerably thicker dorsally. None of the projections figured by Möbius (1856: pl. 8, fig. 4) and described by Richards and Richards (1951: p. 64) were present. The envelope was incomplete ventrally, and the single comb exposed. There were approxi- 
mately 95 cells. Eggs were present in nearly all of these, attached to sides of the cells just above the base.

The adults taken numbered 48 , and three wasps escaped. Of the captured wasps, five were queens and 42 workers. One wasp was classified as intermediate, with an ovariole index of 1 but no developed eggs. It was our impression that its oocytes were degenerate, and we included it with the workers in the statistical analyses. Morphometric measurements included maximum width of metasomal tergum II as well as length of the discal cell. These were found to be significantly correlated with each other (all $\mathrm{N}=48, \mathrm{r}=.410$, $\mathrm{p}<.01)$, and with ovariole index $(\mathrm{r}=.375$ for tergal width and .499 for discal cell length, all $p<.01)$. Hamulus number was not correlated with the morphometric measures $(\mathrm{r}=.072$ for tergal width and -.082 for discal cell length) or ovariole index $(r=.198)$. The queens were found to be significantly larger than the workers in both tergal width (mean $=2.49 \mathrm{~mm}$ versus $2.40 ; \mathrm{t}=4.350, \mathrm{p}<.002)$ and discal cell length $($ mean $=4.91 \mathrm{~mm}$ versus $4.66 ; \mathrm{t}=4.322, \mathrm{p}<.004)$. They did not differ in hamulus number $(t=-1.662)$.

Richards and Richards (1951) studied four colonies of this species. They compared eight queens and eight workers (presumably determined solely by ovarian development) for five morphometric characters, and found no differences. Width of tergum Il was not among these characters. They compared average wing length and hamulus number for ten queens and 33 workers, and found no differences. Their sample sizes were smaller than ours, and drawn from colonies in several stages of development (e.g. two colonies had two combs, and one of these had males). The fact that our colony had a larger number of workers than any of the colonies they studied, but a brood consisting entirely of eggs, suggests that this colony was the recent product of a swarm. This is supported by the incomplete envelope of our colony. Therefore the larger size of queens found by us may be characteristic of recently initiated colonies of this species, and not necessarily mature colonies.

\section{Brachygastra scutellaris:}

One colony of this species (82-02-11-1) was collected at Voltzberg Camp on February 11. It was on a branch tip of small Clusia tree on the granite outcrop near the camp. The nest was about 1.65 $\mathrm{m}$ high and readily visible. In general appearance it was of much the same form as Fígs. 7 and 8 of Richards and Richards (1951). The 
envelope was brownish-gray and quite flexible. The paper consisted of fine whitish fibers and plant epidermal fragments. Some thickening of the envelope had occurred, but was not uniform. The envelope for each comb appeared to be the result of a single construction effort, and was attached to the edge of the combs. The entrance was at the edge of the ventral surface, and more or less continuous with the entrances to each comb.

There were three combs. The oldest, basal comb contained 113 cells, of which 48 were capped and contained pupae. These were concentrated in the center of the comb. Many of the pupae were melanized, and three adults were emerging as the nest was collected. The cells around the periphery of the capped cells contained 11 late-instar larvae. The second comb consisted of 163 cells, of which 118 were capped and contained pupae and prepupae. In addition, 16 uncapped cells contained late-instar larvae. The third comb had 232 cells. There were 18 early-instar larvae scattered about the comb, and an indeterminate number of eggs at the bottom of many cells (the edges of the comb were crushed, but the cells did not appear to have eggs).

The number of adults taken was 112; 2 escaped. Among the captured wasps were 23 teneral individuals classified as "callow". These were measured and dissected, but omitted from most of the statistical analyses (all had filamentous ovarioles). The remainder consisted of 34 queens, 22 intermediates and 33 workers. Measurements included maximum width of metasomal tergum II in addition to length of the discal cell. Following Richards and Richards (1951) for the species myersi, the number of individuals with reddening of the proximal part of the metasoma, and the degree of yellow coloring of the scutellum were recorded.

Tergal width and discal cell length were significantly correlated (all $\mathrm{N}=112, \mathrm{r}=.271, \mathrm{p}<.01$ ). Neither measure was correlated with hamulus number $(r=-.046$ for tergal width, .214 for discal cell length), although the alpha level was close to .05 for discal cell length. Discal cell length was significantly correlated with ovariole index $(r=.309, p<.01)$, but tergal width $(r=.080)$ and hamulus number $(r=.171)$ were not. No significant association of measurements with color pattern were found. When the three castes were compared by ANOVA, width of tergum II was not different $(F=1.08, d f=88)$. Length of the discal cell was significantly differ- 
ent, with queens having longer wings (mean $=2.71 \mathrm{~mm}$ versus 2.57 for intermediates and 2.62 for workers, $F=24.54, \mathrm{df}=88, \mathrm{p}<.005$ ). Hamulus number was not different $(F=2.39, \mathrm{df}=111$; callows included), but when intermediates were lumped with workers queens were found to have a significantly higher average value (mean $=7.5$ versus $7.2 ; \mathrm{t}=2.604, \mathrm{p}<.02$ ). When reddening of the metasoma was tested by a chi-square for differences among castes, workers were found to have a greater degree of reddening than expected, and queens were darker than expected (none had any reddening), with intermediates falling between $\left(X^{2}=13.31, \mathrm{df}=2\right.$, $\mathrm{p}<.005$ ). Scutellar color could not be tested in this way, as almost all specimens were classified as "entirely yellow"; obviously there were no differences between castes.

Richards (1978) reported on two colonies of B. scutellaris. He dissected 173 individuals, evidently preserved in alcohol, and compared 30 queens with 30 workers (drawn equally from the two nests) for forewing length, number of hamuli, number of hamuli per $\mathrm{mm}$ of wing length and width of tergum II. Color pattern was also compared, but he did not give details. Richards did not find differences in most of these features, but detected a significant difference in hamulus number, with queens having a smaller mean number (7.07 versus 7.53 ). This result is directly contrary to ours, but again, there are problems with his classification into castes. He evidently separated intermediates from queens on the basis of size of the eggs ("partly developed" versus "large"), but stated that this division was "not sharp" in the first colony and termed the egg counts "rather arbitrary" in the second colony. He did not record any intermediates for the second colony but stated that some of the queens "might have been called intermediates". It is therefore likely that some individuals were misclassified. Our sample size was larger than his, and his result of a significantly lower mean hamulus number but a slightly larger size for queens than workers (differences not significant) is contrary to the presumed general relationship (Richards, 1949), as well as to the results of our study. It is possible that the relationship varies between colonies, but there is probably a general tendency for queens to be larger in this species. Color pattern is apparently largely independent of reproductive status. Scutellar color was not associated with caste or ovariole development in our colony, and Richards and Richards (1951) found opposite tenden- 
cies in the two colonies of the closely related species B. myersi. Their results for metasomal reddening for one nest were similar to ours (association of this and caste were not reported for the other colony), with reddening occurring only in workers among their dissected wasps. The basis of this association is unknown, but it certainly does not arise from any "effect of dissection" as the Richardses speculated, for we recorded color before dissection.

\section{Metapolybia cingulata:}

One colony of this species (82-02-08-a) was collected on February 8 at Voltzberg Camp. It was oriented obliquely on a large granite boulder in "mountain savannah" forest, and was about $0.5 \mathrm{~m}$ above the ground and well shaded. The envelope was of the same color as the lichen- and moss-grown rock face, and so the nest was very well camouflaged. It measured 6.35 by $4.45 \mathrm{~cm}$ in surface area, and the entrance was on the upper surface towards the lower end. The paper was green-gray, very flexible and composed of crumbly fragments in a matrix of secretion. It was uniformly thin. The secretion formed the "windows" (Richards and Richards, 1951) scattered throughout the envelope. The paper forming the comb was brown and composed entirely of granular material overlain by secretion. The cells were separated from the envelope, and there were a minimum of 222 (some were destroyed during removal). No brood was found.

Adults collected numbered 38, and approximately ten escaped. There were two queens, 33 workers and three males. Among the workers, four had an ovariole index ranging from 1 to 4 but none of these had any "developed" eggs (length greater than $0.6 \mathrm{~mm}$ ). They were therefore treated as workers in the analyses. Measurements included maximum width of tergum II and length of discal cell. These were significantly correlated with each other (all $n=35$, $\mathrm{r}=.586, \mathrm{p}<.001)$, but not with hamulus number $(\mathrm{r}=.208$ for tergal width, .188 for discal cell length). None of these measures was correlated with ovariole index $(r=.179$ for tergal width, .115 for discal cell length and .182 for hamulus number). Queens were not different from workers in tergal width $(t=.699)$ or hamulus number $(t=1.2216)$. In length of the discal cell, the castes differed significantly by a t-test (mean $=2.74 \mathrm{~mm}$ for queens versus 2.82 for workers, $\mathrm{t}=-4.776, \mathrm{p}<.001$ ), but not by a Mann-Whitney test $(T=14)$. The former test has more power, but in view of the small 
number of queens it is probably best not to attach great importance to the result. In a previous study of this species (Richards and Richards, 1951) no external indication of caste was found, and our findings are in line with this.

\section{THE LARVA OF BRACHYGASTRA SCUTELLARIS}

As noted previously, Reid's (1942) description was actually of the species myersi. A series of larvae from a second colony of B. scutellaris was present in material from the British Museum (Natural History) examined by the senior author; the label data are: Brazil: MT, base Camp, dry forest/22.IX.68.N. 152. OWR". The following description is based upon both colonies. All measurements are of late-instar individuals.

Length 5.7-7.8 mm; maximum width $2.2-3.5 \mathrm{~mm}$. Head and body pale. Dorsal lobes (paired ridges) present on first 4 abdominal segments. Pleural lobes strongly developed; no division into annulets. Integument essentially smooth. All spiracular openings subequal in size, more or less circular. Anus with ventral lips forming a bilobed slit.

Head width 1.6-1.8 mm; height (exclusive of labrum) $0.6-0.8$ $\mathrm{mm}$. Head capsule very soft. Setae scattered over surface, varying in number (fig. 3). Ecdysial line and parietal bands weakly indicated, the latter smooth. Anterior tentorial pits below antennal orbits. Clypeus of the usual polistine form; frontoclypeal sulcus effaced dorsally. Labrum approximately as wide as interantennal distance, sinuate; surface roughened ventrally, with 8-10 or more papillae. Mandible as in fig. $5 ; 2$ or 3 setae on external surface. Maxilla as in fig. 4; bases further apart than mandibular bases. Labium setate; salivary opening a raised transverse slit behind palpi.

In addition to scutellaris, specimens of $B$. augusti, bilineolata, moebiana and lecheguana from the collection of the British Museum have been examined. The more transverse shape of the head in fig. 3 than the species figured in Reid (1942) and Dias Filho (1975) is perhaps a preservational artifact, related to the softness of the head capsule. However, it was present, with some variation, in all specimens seen. The genus is also uniform in the setae of the head capsule and the mandible with a weak ventral tooth, both diagnostic characters in Richards (1978). Presence of setae on the mandibles is 

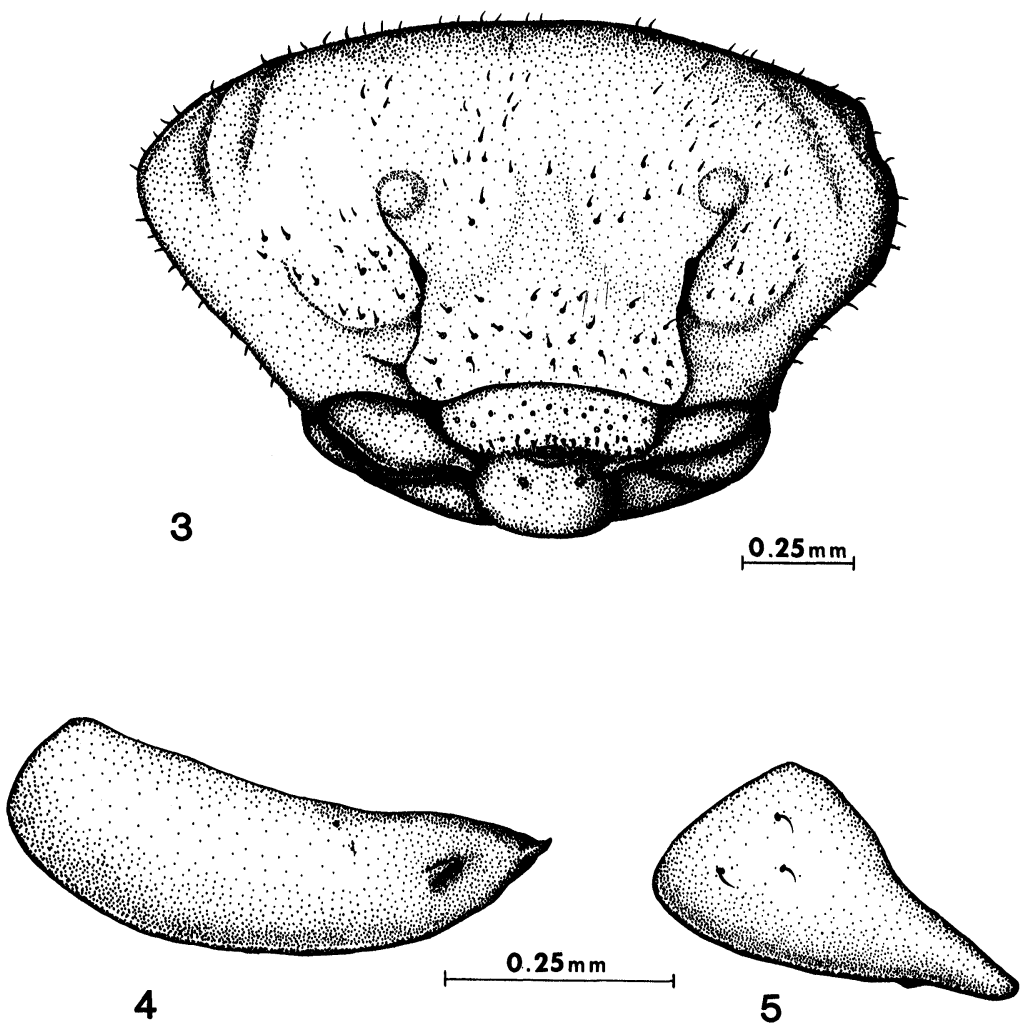

Figs. 3-5. Larva of Brachigastra scutellaris: 3, frontal view of head capsule; 4, mandible; 5 , maxilla.

another major character in Richards' key to genera (with the exception of lecheguana), but care must be used in this feature. Number of setae varied within the 2 colonies, but was always low.

\section{CONCLUSION}

Our results support the general view that caste dimorphism is poorly developed or absent among Polistinae. Where differences were found (Polybia catillifex, Brachygastra scutellaris), queens were larger than workers. Among the Polistinae where differences have been detected, queens are the larger caste, except in a few 
swarm-founding species (Jeanne, 1980). Such morphological differences between reproductives and non-reproductives may vary between colonies of the same species (Richards and Richards, 1951; Jeanne and Fagen, 1974; this paper) and within colonies over the course of a normal cycle. Moreover, although morphological caste differentiation is not pronounced in the Polistinae, behavioral and functional differentiation is well developed (West Eberhard, 1978).

Lack of pronounced morphological caste dimorphism has been taken to indicate a less advanced level of eusociality in the Polistinae relative to the Vespinae (e. g. Iwata, 1976). However, by other criteria of social complexity (mode of suppression of nestmate reproduction, colony size, duration of colonies), the swarm-founding Polistinae are at a comparable level of sociality to the Vespinae (Jeanne, 1980). The difference in degree of caste dimorphism between the two groups of highly social wasps undoubtably reflects ecological constraints of the environments in which they have evolved (Richards, 1971), with the strong queen/worker dimorphism of the Vespinae part of an adaptive syndrome linked with winter hibernation and a short colony life cycle (Richards, 1971). The differences in adult size between queens and workers of some polistine species suggest that in these species caste differentiation is either pre-imaginal, or that males preferentially mate with females possessing certain morphological attributes (or that only these females are receptive to mating). These competing hypotheses must be tested in species in which caste dimorphism has been firmly established.

Although dissection and morphometric study of individuals collected with nests are likely to remain the primary methods of analysis of social structure in tropical polistines, the information provided is limited. A proper understanding of the social biology of these wasps requires in-depth behavioral studies of natural colonies.

\section{ACKNOWLEDGEMENTS}

Deborah R. Smith of Cornell University assisted in collection of colonies. M. C. Day of the British Museum (Natural History) arranged the loan of Brachygastra larvae. We should like to thank Janice S. Edgerly of Cornell University for the figures of the larva and G. C. Eickwort of Cornell University for critical review of the manuscript. Field work in Suriname was supported by grants from Sigma Xi, the Explorers Club and the Griswold Fund of the Department of Entomology of Cornell University. 


\section{Literature Cited}

AKRE, R. 1982. Social wasps. pp. 1-105 in Hermann, H. (ed.) Social Insects IV. Academic Press, NY.

Cumber, R. A. 1949. The biology of bumblebees with special reference to the production of the worker caste. Trans. R. Entomol. Soc. Lond. 100: 1-45.

Dias Filho, M. M. 1975. Contribuição à morfologia de larvas de vespideos sociais do Brasil (Hymenoptera, Vespidae). Rev. Bras. Ent. 19: 1-36.

Jeanne, R. L. 1973. Aspects of the biology of Stelopolybia areata (Say) (Hymenoptera: Vespidae). Biotropica 5: 183-198.

1980. Evolution of social behavior in the Vespidae. Ann. Rev. Entomol. 25: 371-396.

JeAnne, R. L. AND R. Fagen. 1974. Polymorphism in Stelopolybia areata (Hymenoptera: Vespidae). Psyche 81: 155-166.

Möвıыs, K. A. 1856. Die Nester der geselligen Wespen. Hamburg.

REID, R. A. 1942. On the classification of the larvae of the Vespidae (Hymenoptera). Trans. R. Entomol. Soc. Lond. 93: 285-331.

Richards, O. W. 1949. The significance of the number of wing-hooks in bees and wasps. Proc. R. Entomol. Soc. Lond. (A)24: 75-78.

1971. The biology of the social wasps (Hymenoptera, Vespidae). Biol. Rev. 46: 483-528.

1978. The social wasps of the Americas excluding the Vespinae. Brit. Mus. (Nat. Hist.), London.

Richards, O. W. AND M. J. Richards. 1951. Observations of the social wasps of South America (Hymenoptera: Vespidae). Trans. R. Entomol. Soc. Lond. 102: $1-170$.

Velleman, P. F. And D. C. Hoaglin. 1981. Applications, Basics, and Computing of Exploratory Data Analysis. Duxbury Press, Boston.

West EBERHARD, M. J. 1978. Temporary queens in Metapolybia wasps: nonreproductive helpers without altruism? Science 200: 441-443. 

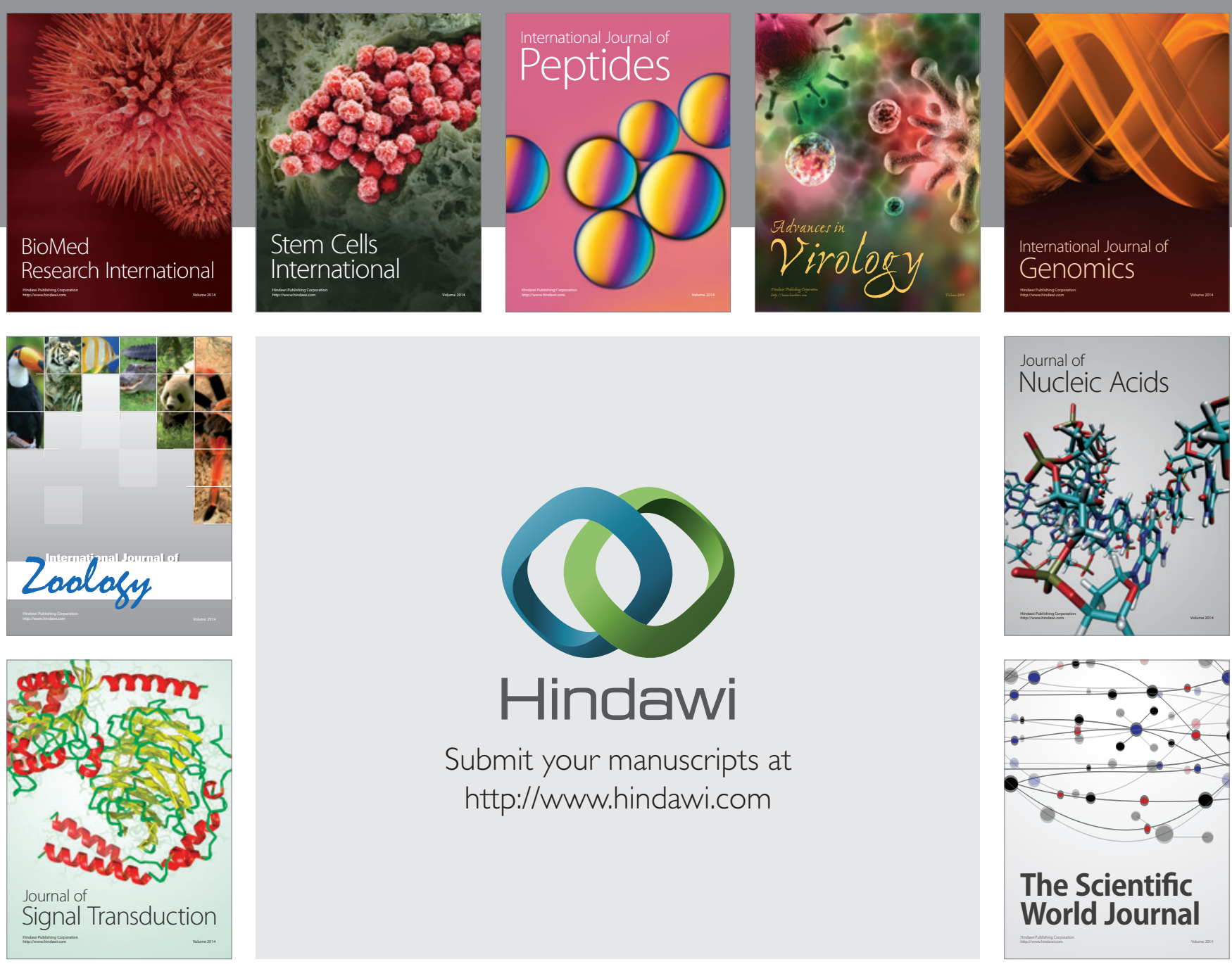

Submit your manuscripts at

http://www.hindawi.com
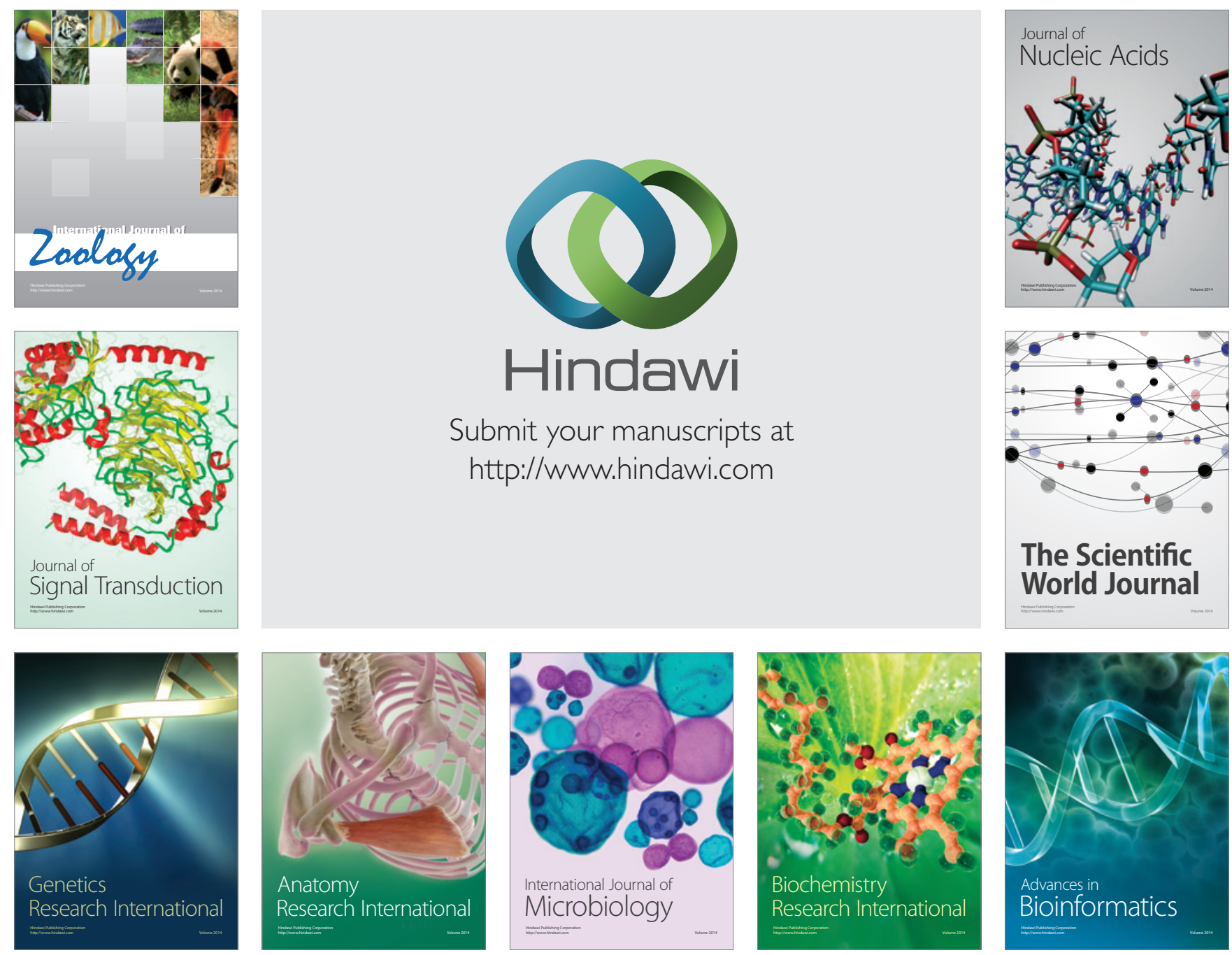

The Scientific World Journal
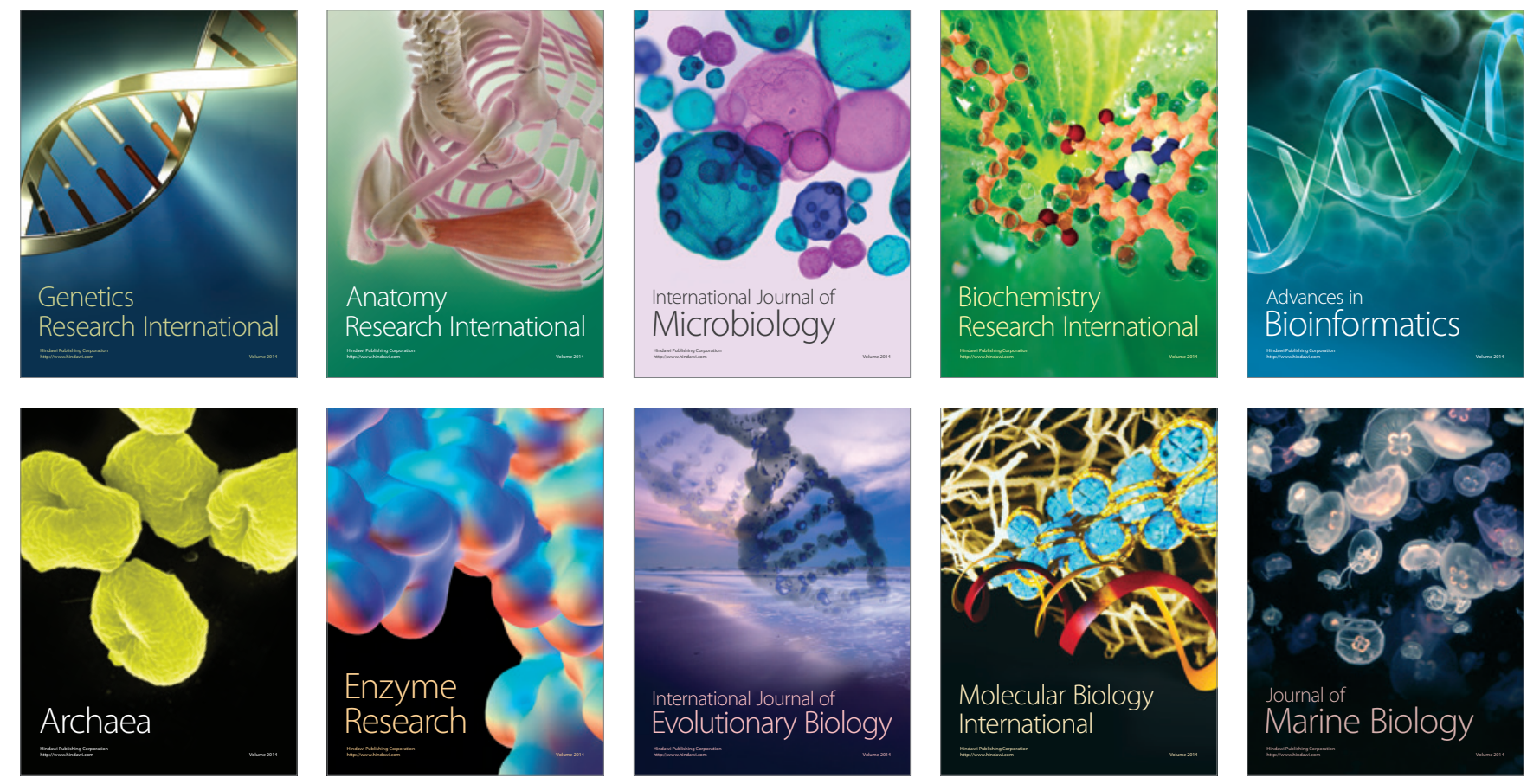